\title{
GAS DISCHARGE STATIC CHARACTERISTICS IN PULSE REGIME
}

\author{
M. Zlatanović, 'I. Popović \\ University of Belgrade, School of Electrical Engineering, \\ Bulevar Kralja Aleksandra 73, 11120 Belgrade, Serbia
}

\begin{abstract}
The application of pulse DC power supply resulted in a significant advance of plasma surface processing of materials compared to continuous DC supply. The synthesis of new materials and various surface structures formation was provided, as well as a reliable operation due to introduction of new process parameters such as pulse frequency and duty cycle and due to suppression of glow-to-arc transitions. As a result, physical and chemical processes on the material surface can be controlled by new pulse generator parameters, but their complex dependence on cathode physical properties and cathode geometry, as well as on working gas composition remained. On the other hand, time and space process efficiency is to some extent lowered compared to continuous DC plasma treatment due to periodic transition to the stationary state. In order to improve process efficiency, pulse generator parameters should be set to provide system transition to the stationary state during the pulse period.

In this paper we investigated gas discharge static characteristics, after the discharge spread over the whole cathode surface. It was found that static discharge characteristics were mostly dependent on the working pressure. The static resistance of the discharge decreased with increasing of discharge voltage and decreasing the cathode temperature. It was concluded that the cathode heating can be performed at the constant discharge current by slowly increasing pulse power supply voltage.
\end{abstract}

Keywords: gas discharge, static characteristics, pulse plasma processes, surface treatment.

\section{INTRODUCTION}

Introduction of pulsed direct current power supply in plasma deposition and diffusion processes provided significant advance in new materials synthesis and plasma surface engineering, as well as in control and stability of processing. Compared to continuous DC supply, the number of parameters which determine the quality of treated surface, process characteristics and operating procedure is increased. The power supply pulse frequency, duty cycle and output voltage level directly influence the properties of surface structure and quality, while the process stability and control are improved by a relatively simple arc suppression system and post relaxation time adjustment [1-3].

In addition, the complexity of workpiece geometry and topology of the pulse generator output circuit influence the process control. A system for plasma treatment which consists of two complex geometry electrodes (anode and cathode) placed in the vacuum chamber filled with the binary gas mixture, may be considered as a gas diode with the cathode temperature, total gas pressure and gas mixture composition as the characteristic parameters. The control and the results of a reactive DC pulse plasma processing depend on the substrate surface characteristics, process parameters, system geometry and power supply characteristics [4].

The analysis of the electrical response of processing gas discharge as a load is important in terms of the development of process control algorithm as well as for better understanding of thermo-chemical processes. The data on the thermo-chemical processes is partially included in the signal waveforms. Glow discharge in the case of unipolar DC pulse biasing includes the discharge ignition, transition to the stationary state with characteristic relaxation times for various processes and for discharge spreading over treated surface, stationary state operation and discharge breakdown $[3,4]$.

After the completion of time-space transition processes which are related to system dynamic characteristics, glow discharge reaches the stationary

* Corresponding autor: mzlatanovic@beotel.net 
state determined by system static characteristics [5-8]. The gas discharge static characteristics are dominant in the case of low frequency unipolar pulse biasing at high duty cycle ratio. In this case the process efficiency is improved, but the possibility of discharge instabilities occurrences in the form of glow to arc transition is enhanced. This paper deals with the analysis of gas discharge static characteristics in the case of unipolar pulsed DC plasma surface treatment of the material in diode system configuration.

\section{GAS DISCHARGE EQUIVALENT PARAMETERS}

The measurements were performed by recording the gas diode voltage and current waveforms in grounded anode cold wall vessel configuration as shown in experimental setup presented in Fig. 1. The working atmosphere pressure adjustment was made in the dynamic regime by balancing the hydrogen flow rate and pumping speed using corresponding control valves. The electrical signal waveforms were recorded over the range of working pressures characteristic for the active surface treatment and also at low pressure range when ion-bombardment is used for workpiece surface cleaning and for cathode heating process. The frequency of the generator unipolar DC pulses was varied in the range from $90 \mathrm{~Hz}$ to $20 \mathrm{kHz}$, while the duty cycle ratio was in the range from $5 \%$ to $96 \%$.

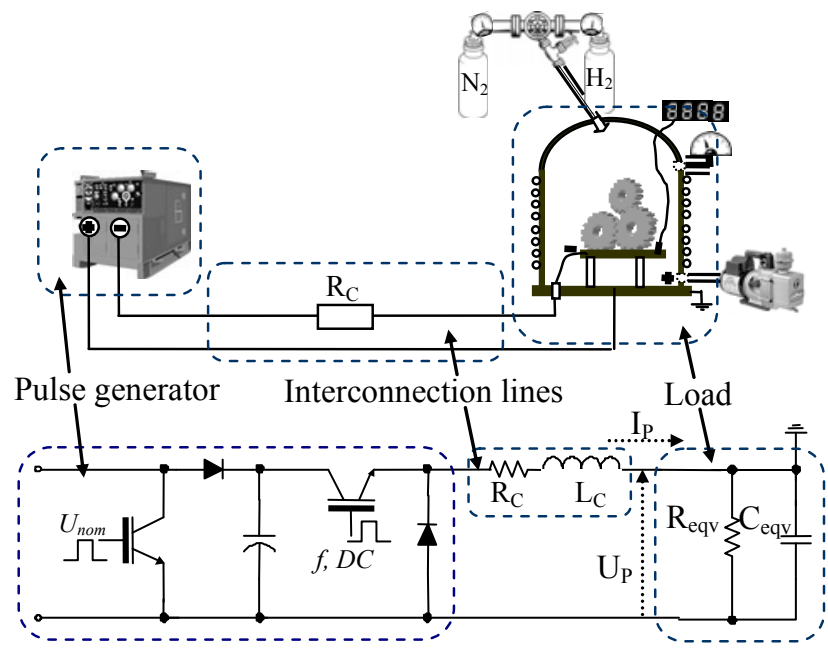

Figure 1. Simplified plasma deposition system and corresponding equivalent electrical circuit

Based on the analysis of the electrical signal waveforms, the equivalent electrical circuit of the system presented in Fig. 1 was obtained. The output stage of pulse generator provided the voltage level, frequency and duty cycle tuning through the control of the switching IGBT transistor. The circuit for the interconnection of the vacuum chamber and generator output consists of current limiting resistor and power lines. The coupling circuit electrical model includes the parasitic inductance of a current limiting resistor. The gas discharge electrical model was determined based on analysis of low pressure system response when cathode voltage shape corresponds to the first order circuit response. As the vacuum chamber physically represents a capacitor with the working gas being imperfect dielectric, the gas diode was modeled by the equivalent discharge resistance and capacitance connected in parallel. [2,4,7].

Since the gas diode physically represents an electrical load in the form of two electrodes placed in the vacuum chamber filled with the gas mixture at low pressure, an increase in gas molecule concentration with the increase of total gas pressure is expected. As a result, an increase in the gas diode equivalent capacitance is expected due to the increase of gas dielectric constant cased by increased concentration of atoms and molecules [9]. The discharge equivalent capacitance is not analyzed in this paper since it determines system dynamic behavior during the transition processes in the gas diode and has no direct implication on gas discharge static characteristics.

In the simple approximation, after the discharge transition to the stationary state, the electrical behavior of the gas diode can be represented by a ratio of the cathode voltage level and discharge current in the form of gas discharge static or equivalent resistance. At low pressure, after the transition of discharge to the stationary state the generator output voltage corresponds to the cathode voltage since the nominal discharge current produces negligible voltage drop over the current limiting resistor.

The diode static equivalent resistance depends on the total gas discharge pressure. In stationary regime, a decrease of the gas discharge equivalent resistance with the increase of the total gas pressure is expected. This is a consequence of amplification of the gas ionization processes which result in increased concentration of generated charge particles. The discharge current is increased due to charged particles recombination at the electrodes even at no or small increase of discharge voltage. The equivalent discharge resistance determines the electrical behavior of the gas diode as a load after the discharge transition to the stationary state.

The discharge current in stationary regime varies significantly with the variation of the total gas pressure but is also dependant on the cathode temperature and binary gas mixture composition. The gas 
discharge equivalent parameters related to discharge current are also dependant on total gas pressure, gas mixture composition, cathode temperature, cathode geometry and cathode material properties. During surface treatment the initial steps of surface cleaning by the ion bombardment is performed at low discharge pressure, while the workpiece heating and its surface treatment require total pressure in the order of few milibars. Therefore, the recording of gas discharge static characteristics was performed at low and working pressure regimes.

\section{EQUIVALENT STATIC RESISTANCE AS A FUNCTION OF PRESSURE}

The discharge static resistance is defined as a ratio of the cathode voltage level and discharge current in the stationary state and is given by the relation:

$$
\mathrm{R}_{\mathrm{e} q v}=\frac{U_{p}}{I_{p}}
$$

In relation (1), $U_{p}$ and $I_{p}$ represent the voltage across the gas diode (negative cathode voltage) and discharge current after the gas transition to the stationary state, respectively.

Fig. 2 presents the equivalent gas discharge static resistance vs. total gas pressure at low discharge pressure region.

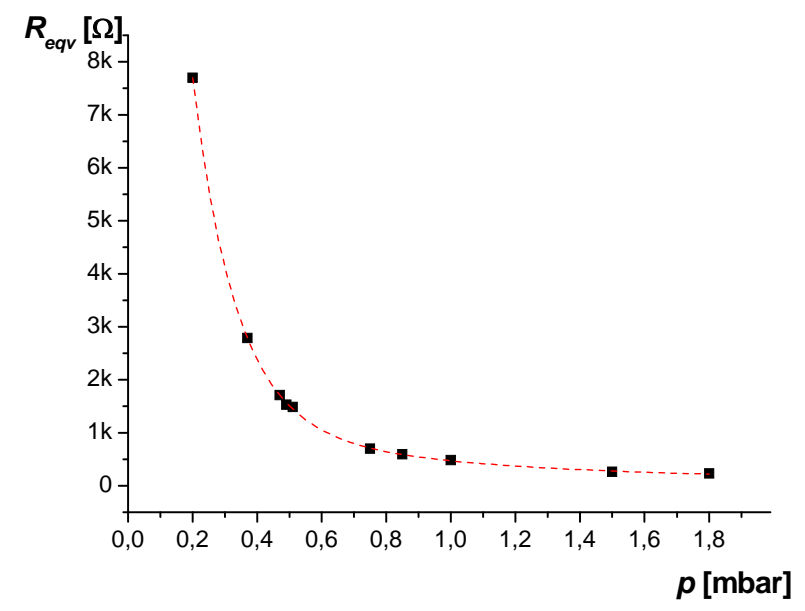

Figure 2. Gas discharge static resistance as a function of pressure in low pressure region

In low pressure region the gas discharge static resistance as a function of pressure may be approximated by the relation:

$\mathrm{R}_{\mathrm{e} q v}(p)=y_{0}+y_{1} e^{-p / p_{1}}+y_{2} e^{-p / p_{2}}$
The coefficients $y_{0}, y_{1}, y_{2}, p_{1}$ i $p_{2}$ in relation (2) were calculated by incorporating the experimental data given in Fig. 2. The analysis based on relation (2) and the experimental data from Fig. (2) show that in low pressure region the gas discharge static resistance varies in several order of magnitude. In the stationary state, the gas discharge diode as a load connected to pulse power supply may be presented as an equivalent resistance which is very sensitive to total operating pressure variation. The exact value of the equivalent resistance depends on the vacuum chamber geometry and shape of electrode shape and properties of material.

\section{GAS DISCHARGE STATIC CHARACTERISTICS}

At the given cathode voltage level the discharge current depends on operating pressure since the gas discharge static resistance is pressure dependent. Additionally, gas discharge current varies with a change of the cathode temperature for given cathode voltage. The cathode temperature was measured by $\mathrm{K}$-type thermocouple mounted in the cathode and electrically insulated from the cathode potential. The current-voltage characteristics of the gas discharge diode at different cathode temperatures in stationary state are presented in Fig. 3. The experiments were performed for the cathode temperatures from $175^{\circ} \mathrm{C}$ to $440^{\circ} \mathrm{C}$.

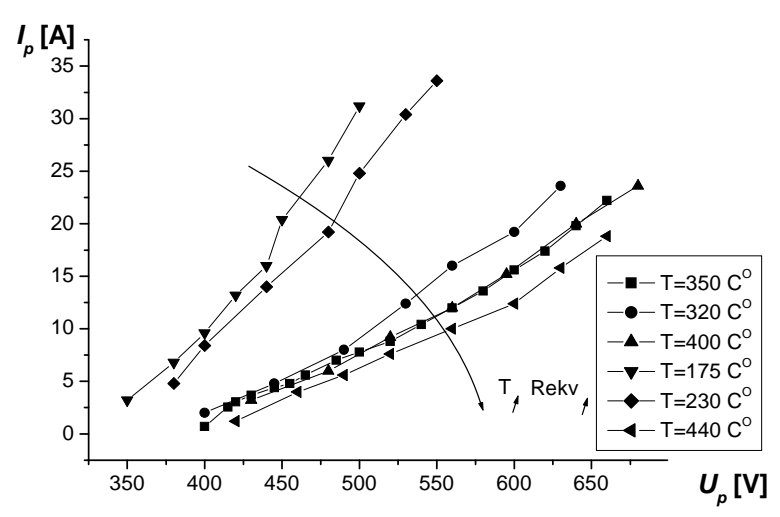

\section{Figure 3. Current-voltage characteristics at different cathode temperatures in stationary state}

As it can be seen in Fig. 3, an increase in cathode temperature causes a decrease of discharge current at the same generator output voltage. It is possible to keep the constant discharge current during the ion bombardment heating of the cathode by smooth increase of the cathode voltage. This is important in the case of plasma nitriding process in cold wall ves- 
sel configuration and is confirmed in the experiment. The gas discharge static resistance, calculated as the ratio of the cathode voltage and discharge current in stationary state, increases with the rise of cathode temperature.

The dependence of the gas discharge static resistance on the cathode temperature is given in Fig. 4 at the plasma generator output voltage level was varied in the range from $420 \mathrm{~V}$ to $520 \mathrm{~V}$.

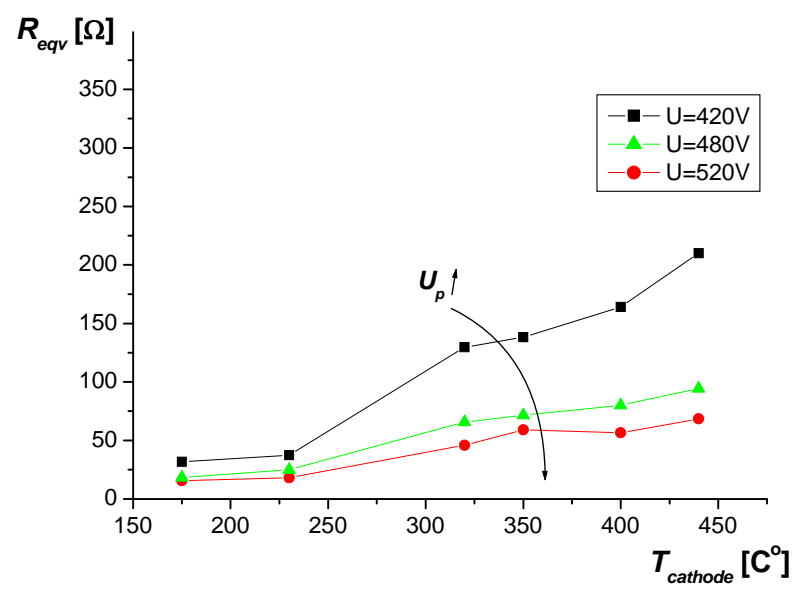

Figure 4. Gas discharge static resistance versus cathode temperature at different cathode voltages

It follows from the diagram presented in Fig. 4 that the gas discharge static resistance decreases with a rise of generator output voltage level. By the cathode voltage increase the energy transferred to free electrons in working gas from the external electrical field increases, so that the concentration of charge particles generated in electron-gas molecules ionization processes also increases. The same conclusion could be drawn from the diagram presented in Fig. 3, where the gradient of current-voltage static characteristic is increasing with the generator output voltage increase, as it is the case when the cathode temperature decreases. This relation is illustrated with the equation:

$$
\begin{aligned}
& U_{p} \uparrow\left(T_{\text {cathode }}=\text { const }\right) \Rightarrow \frac{U_{p}}{I_{p}} \downarrow, \\
& T_{\text {cathode }} \uparrow\left(U_{p}=\text { const }\right) \Rightarrow \frac{U_{p}}{I_{p}} \uparrow
\end{aligned}
$$

Besides time-dependent transition processes related to particles interaction in the discharge, there is an occurrence of a "space"-dependent transition processes. In Fig. 5, the dependence of gas discharge static resistance vs. generator output voltage for different cathode temperature is presented.
The analysis of data given in Fig. 5 indicated the existence of two regions in static resistancedischarge voltage curves. At the given cathode temperature, the equivalent resistance is significantly increased below certain value of the output voltage. As a consequence, the corresponding discharge current significantly decreases. These characteristic output voltage values define the voltage border line which separate the region of high static resistance. The border voltage line is shown in the diagram by a dashed curve.

For the cathode voltage below the border value, the glow discharge partially covers the cathode surface. As a consequence, there is an unhomogeneity in space distribution of the discharge over the cathode surface leading to non-homogeneous surface treatment such as non-homogeneous coating properties. A similar effect could be noticed during the plasma surface treatment at high frequency if the duration of the transition processes is comparable to the voltage pulse duration. There is a characteristic time for the discharge to spread over the cathode. If this time is lower than voltage pulse duration the entire cathode surface will be covered by the glow discharge, more homogenous surface treatment is to be expected and overall process efficiency enhanced. The voltage border line defines transition from normal to abnormal glow discharge characterized by an increase in discharge current density with increasing output voltage. The voltage border line separates the high resistance area from static regime of discharge operation which is used in surface treatment of materials. Depending on voltage pulse level and duration, the static regime of glow discharge could not be attained in some cases due to the glow spreading "space"-dependant processes.

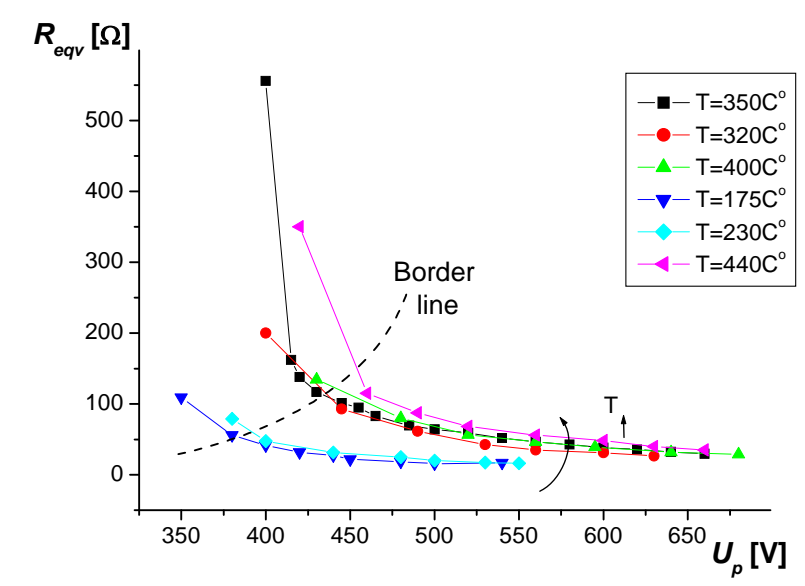

Figure 5. Gas discharge static resistance vs. generator output voltage in stationary regime at different cathode temperatures 
The value of negative cathode voltage at which the glow discharge covers the whole specimen surface significantly increases with the cathode temperature increase, as it can be seen from the voltage border line shown in Fig 5.

As an example, at the cathode temperature equal to $440^{\circ} \mathrm{C}$, the corresponding cathode voltage border value is near $460 \mathrm{~V}$ and discharge current reaches 5A. At lower cathode voltage levels plasma surface produced a non homogeneous surface structure due to non-homogenous temperature distribution over the workpiece surface $[10,11]$.

It should be pointed out that the transition of reactive glow discharge to the equilibrium state is a two-step process which includes charge particles generation and formation of the active species responsible for thermo-chemical processes on the treated material surface [8]. The electrical signal waveforms contain the information directly related to charge particles generation. In addition, a transition from normal to abnormal glow discharge characterized by the start of completely glow covered cathode surface can be detected by the offset of static regime as analyzed in this paper. The static regime of operation provides homogeneous and efficient processes of pulse plasma surface treatment of materials.

Based on the analysis of the presented discharge static characteristics it is possible to conclude that the glow discharge spreading is directly dependent on the generator output signal pulse and pause duration defined by frequency and duty cycle ratio and by the output voltage level of the pulsed plasma generator during the pulse interval. More complex discharge electrical model should contain voltage controlled non-linear model of the discharge equivalent impedance.

The model of pulse DC discharge that qualitatively describes a decrease of the equivalent static resistance with the increase of the cathode voltage is presented in reference [12]. The results presented in this paper show that the discharge model verification should include dependence on the process and biasing parameters, as well as validation of the overall system of electrical response which confirms the importance of system electrical response analyses partially considered in this paper.

\section{CONCLUSIONS}

The stationary regime of glow discharge used in pulse plasma surface treatment was analyzed in order to improve the control and efficiency of technological processes. Besides the process parameters, the electrical response of the system depends on plasma generator output signal, system construction and workpiece geometry. In the static regime the discharge impedance can be considered as an equivalent resistance the value of which varies with different parameters. It was shown that discharge static characteristics are mostly dependent on operating pressure value. In the cold wall configuration of the vacuum chamber heating of the workpiece by ion bombardment is possible to achieve at the constant discharge current by the gradual increase of the cathode voltage level. The discharge current and consequently the efficiency of the plasma surface treatment, is also dependent on workpiece temperature and voltage level at the output of the plasma generator in the course of the pulse duration. The gas discharge static resistance, defined as a ratio of the cathode voltage and current after a glow discharge transition to the stationary state decreases with the generator output voltage increase, and the cathode temperature decrease. The static characteristics data provides the information on the cathode coverage by the glow and consequently the information on the surface treatment homogeneity and efficiency which can contribute to development of the algorithms for control of pulsed direct current plasma surface treatment.

\section{REFERENCES}

[1] J. Laimer, M. Fink, T. A. Beer, H. Störi, Plasma Dynamics as a Key to Successful Upscaling of Pulsed Plasma Processes, Surface \& Coatings Technology, 174-175 (2003) 118-123.

[2] I. Popović, V. Zlatanović, A. Kunosić, M. Zlatanović, Modeling Of Diode Configuration Glow Discharge Impedance Connected To Pulse Power Supply, Surface \& Coatings Technology, 200 (2005) 1659-1663.

[3] I. Popović, V. Rajović, M. Zlatanović, Dynamic Voltage-Current Characteristics of Unipolar Pulse Glow Discharge, Material Science Forum 494 (2005) 315-320.

[4] I. Popović, M. Zlatanović, Influence of Time Domain Parameters on Unipolar Pulse Plasma System Transition State, Materials and Manufacturing Processes 24, 10-11 (2009) 1134-1141.

[5] M. Zlatanović, I. Popović, Uticaj impulsnog napajanja na efikasnost plazma tehnološkog postupka, Zbornik radova Savremeni materijali, Banja Luka 2010, 305-318.

[6] I. Popović, M. Zlatanović, Electrical and Optical Signal Analysis of Pulse Powered Glow Discharge System, Material Science Forum 518 (2006) 337-342. 
[7] E. Guiberteau, G. Bonhomme, R. Hugon, G. Henrion, Modeling The Pulsed Glow Discharge Of Nitriding Reactor, Surface \& Coatings Technology 97 (1997) 552-556.

[8] Y. M. Kim, J. G. Han, Spectroscopic Study for Pulsed DC Plasma Nitriding of Narrow Deep Holes, Surface \& Coatings Technology 171 (2003) 205-210.

[9] S. O. Kasap, Dielectric Materials: Static Relative Permittivity, e-Booklet, (2001).

[10] T. A. Beer, J. Laimer, H. Störi, Study of the Ignition Behavior of a Pulsed D.C. Discharge
Used for PACVD, Vacuum Science Technology A18 (2000) 423-434.

[11] I. Popović, M. Zlatanović, Equivalent Circuit of Unipolar Pulsed Plasma System for Electrical and Optical Signal Analysis, Research Trends in Contemporary Materials Science 555 (2007) 89-94.

[12] D. Mu, Z. Yaru, F. Yuija, Z. Nan, L. Chengsen, W. Dezhen, Modeling of Pulsed DirectCurrent Glow Discharge, Plasma Science and Technology 12, 4 (2010) 447-451.

\title{
СТАТИЧКЕ КАРАКТЕРИСТИКЕ ГАСНОГ ПРАЖЬЕњА У ИМПУЛСНОМ РЕЖИМУ
}

\begin{abstract}
Сажетак: Увођењем импулсног напајања остварен је веома значајан напредак у области плазма технике за обраду површине материјала. Осим синтезе нових материјала и формирања нових површинских структура, процесирање површина у импулсној плазми омогућило је и знатно прецизнију контролу вођења поступка, али је у појединим примјенама просторно-временска ефикасност импулсног плазма процесирања смањена у односу на систем са једносмјерним напајањем. Увођењем нових параметара процеса, као што су учесталост и однос трајања напонског сигнала и периоде побудних импулса, физички и хемијски процеси у радној комори постали су значајно зависни од карактеристика побудних импулса. Са друге стране, остала је комплексна зависност процеса од физичких карактеристика катоде, геометрије третиране површине и састава радног гаса. Ради унапређења ефикасности поступка, параметре побудног генератора потребно је изабрати тако да се у већем дијелу периода побудних импулса гасно пражњење налази у стационарном стању у ком су завршени прелазни процеси ширења гасног пражњења преко површине катоде.

У овом раду анализиран је стационарни режим, односно утицај радног притиска и температуре катоде на статичке карактеристике гасног пражњења и зависност статичких вриједности струје гасног пражњења од вриједности напонског нивоа на излазу импулсног генератора. Показано је да су статичке карактеристике највише зависне од радног притиска, док статичка отпорност опада са порастом излазног напона генератора и са опадањем температуре катоде. Закључено је да се загријавање радног комада може вршити при константној струји пражњења уколико се излазни напон генератора контролисано постепено повећава.
\end{abstract}

Кључне речи: гасно пражњење, статичке карактеристике, процеси у импулсној плазми, површинска обрада. 